\title{
Indirect micro-immunofluorescence test for detecting type-specific antibodies to herpes simplex virus
}

\author{
T FORSEY AND S DAROUGAR
}

From the Virus Laboratory, Department of Clinical Ophthalmology, Institute of Ophthalmology, London, UK

SUMMARY A rapid indirect micro-immunofluorescence test capable of detecting and differentiating type-specific antibodies to herpes simplex virus is described. The test proved highly sensitive and, in 80 patients with active herpes ocular infection, antibody was detected in $94 \%$. No anti-herpes antibody was detected in a control group of 20 patients with adenovirus infections.

Testing of animal sera prepared against herpes simplex virus types 1 and 2 and of human sera from cases of ocular and genital herpes infections showed that the test can differentiate antibodies to the infecting serotypes. Specimens of whole blood, taken by fingerprick, and eye secretions, both collected on cellulose sponges, could be tested by indirect micro-immunofluorescence. Anti-herpes IgG, IgM, and IgA can also be detected.

Various techniques have been used to identify and differentiate antibodies to herpes simplex virus type 1 (HSV1) and type 2 (HSV2). The microneutralisation test, ${ }^{1}$ a plaque reduction test, ${ }^{2}$ measurement of kinetics of neutralisation, ${ }^{3}$ and the detection of antibody-mediated cytolysis ${ }^{4}$ have all been shown to be sensitive but are too complex for routine use. A simpler technique, the modified passive haemagglutination test, ${ }^{5}$ can also differentiate HSV1 and HSV2 antibodies but requires prior cross-absorption of the test sera with antigens to achieve a typespecific result.

Indirect fluorescent antibody techniques have found favour for the study of serum responses to various viruses. ${ }^{6}$ These techniques generally utilise type-specific antigens, which appear in the membranes of infected cells and have been used successfully by Nahmias et al. ${ }^{7}$ and Smith et al. ${ }^{8}$ to study anti-herpes antibodies. However, the requirement for prior absorption of sera, the nature of the antigens in infected cells, and the skill required to recognise specific membrane fluorescence make these techniques difficult to apply routinely.

A microtitre fluorescent antibody technique using purified antigens has been developed by Wang and Grayston $^{9}$ and modified by Treharne et al. ${ }^{10}$ to

Received for publication 11 June 1979 detect antibodies to chlamydia. This test is capable of differentiating immunoglobulin classes of antibody to all known chlamydial serotypes and can detect antibody in serum, in whole blood, and in ocular and genital secretions. This test is used routinely in our laboratory for the diagnosis of chlamydial infections of the eye ${ }^{11}$ and cervix. ${ }^{12}$ Because of its simplicity, we have adapted this technique for the detection and differentiation of antibodies to herpes simplex virus.

In this paper we present details of an indirect micro-immunofluorescence (IF) test developed for detecting different immunoglobulin classes of typespecific anti-herpes antibodies, and we report the results of testing sera and eye secretions using this new technique.

\section{Material and methods}

ANTIGENS

Herpes simplex virus type 1 (VRL/10711) and type 2 (Bryan strain) were obtained from the Central Public Health Laboratory, London. Each type was propagated in HeLa 229 cell culture (Flow Laboratories, Scotland) and passaged to produce virus stocks. It was necessary to passage each type into four 2-litre roller bottles of cells to produce sufficient quantities of virus. Infected cells were harvested when $90-100 \%$ 
of cells showed a cytopathic effect. Medium was removed from the bottles and mixed with polyethylene glycol (final concentration $8 \% \mathrm{w} / \mathrm{v}$ in the presence of $0.5 \mathrm{M} \mathrm{NaCl}$ ) to precipitate free protein, including virus. ${ }^{13}$ The precipitate was pelleted by centrifugation at $1000 \mathrm{~g}$ for 10 minutes at $+4^{\circ} \mathrm{C}$ and then resuspended in approximately $10 \mathrm{ml}$ phosphate buffered saline (PBS), pH 7.4.

Infected cells were stripped from the bottles by adding approximately $20 \mathrm{ml}$ distilled water to each and shaking with small glass beads for 2 minutes. Cell harvest and media precipitates were pooled (four roller bottles yielded approximately $100 \mathrm{ml}$ ) and freeze-thawed three times to disrupt the cells. This harvest was then centrifuged at $1000 \mathrm{~g}$ for 10 minutes at $+4^{\circ} \mathrm{C}$ to remove gross debris. The supernatant then appeared opalescent and free from large particles and was centrifuged at $48000 \mathrm{~g}$ for 2 hours at $+4^{\circ} \mathrm{C}$ to pellet virus particles. This pellet was resuspended in one-tenth the original volume of PBS, $\mathrm{pH} 7 \cdot 4$, by vigorous shaking with small glass beads.

The infectivity titres of these preparations were estimated using a plaque assay technique, ${ }^{14}$ and each virus was found to contain approximately $10^{9}$ plaque-forming units per millilitre (PFU/ml).

Each virus type suspension was then mixed with uninfected fertile hen's egg yolk to achieve a final concentration of $5 \% \mathrm{v} / \mathrm{v}$ yolk in order to enhance the adhesion of antigens to the slides and to provide a background to the antigen dots, which aided location during microscopy. These antigens were then dispensed into $0.3 \mathrm{ml}$ aliquots and stored at $-70^{\circ} \mathrm{C}$.

Uninfected HeLa cells were similarly processed to prepare a control antigen.

\section{ANIMAL SERA}

Antisera against HSV1 and HSV2 were prepared in mice. Ten 3-4-week-old albino Swiss female mice were used for each virus type. Each mouse was inoculated intravenously via the tail vein ${ }^{9}$ with 0.5 $\mathrm{ml}$ of prepared antigen without yolk diluted to $10^{3}$ PFU $/ \mathrm{ml}$ in PBS, pH 7.4 (day 0). A further inoculation was given on day 7 , and mice were exsanguinated three days later (day 10). Exsanguination was carried out by anaesthetising the mice with ether, opening the ventral skin layer, and cutting the axillary plexus. Arterial blood drained into the pocket formed between the skin and the thorax and was withdrawn with a pipette. Blood was pooled for each virus type, and the serum was separated and stored at $-20^{\circ} \mathrm{C}$. Sera were absorbed with equal volumes of control antigen for 1 hour at $37^{\circ} \mathrm{C}$ and then overnight at $+4^{\circ} \mathrm{C}$ before testing.

Commercially available rabbit anti-HSV1 and anti-HSV2 sera prepared from antigens produced in rabbit cornea cells (Mercia Brocades Ltd, UK) were also used in the test without prior absorption.

\section{HUMAN SERA}

Blood from 92 patients, 70 with herpetic ocular infections, two with herpetic genital infection, and 20 with adenovirus keratoconjunctivitis, was collected by venepuncture. Sera were separated after clotting and stored at $-20^{\circ} \mathrm{C}$.

In a further 10 patients with herpetic ocular infection, eye secretions (tears) and whole blood, taken by finger-tip pricking, were collected using cellulose sponges, as described by Darougar and colleagues. ${ }^{11}$

\section{INDIRECT MICRO-IMMUNOFLUORESCENCE}

(IF) TEST

Microscope slides were thoroughly cleaned by scrubbing with detergent, and rinsed three times in tap water, three times in distilled water, and finally in absolute ethanol. Slides were stored under alcohol until used. Antigen micro-dots were applied to slides using sterile mapping pen nibs (Cumberland Graphics Ltd, UK) previously degreased with ether. Separate nibs were used for each of the three antigens (HSV1, HSV2, and control). Antigens were arranged in nine clusters on each slide using a template to aid location. Slides were then air-dried for 30 minutes and fixed in acetone for 10 minutes at room temperature. Fixed slides were stored at $-20^{\circ} \mathrm{C}$ until used.

Dilutions of sera, blood, and tears were prepared with PBS, $\mathrm{pH} 7 \cdot 4$, as diluent, and appropriate dilutions were overlaid onto the antigen clusters fixed on slides using a bacteriological loop. Slides were then incubated in a humid chamber for $\mathbf{3 0}$ minutes at $35^{\circ} \mathrm{C}$ and then thoroughly washed for 10 minutes in PBS, $\mathrm{pH} 7 \cdot 4$, using staining troughs and a magnetic stirrer. They were then air-dried, and the antigens were covered with the appropriate antiserum conjugated with fluorescein isothiocyanate (FITC) as a second layer. Incubation, washing, and drying were repeated as before.

Swine anti-mouse and anti-rabbit whole globulin FITC conjugates (Nordic Immunological Laboratories, UK) were used to stain the animal sera, and swine anti-human IgG, IgM, and IgA FITC conjugates (Hyland Laboratories, UK) were used for the human sera. Rhodamine bovine albumin (Difco Laboratories, UK) was used as counterstain, and all conjugates were previously titrated to determine their optimum working dilutions.

Stained slides were mounted in buffered glycerol (9 parts glycerol: 1 part PBS, $\mathrm{pH} 8.5$ ) and examined at a magnification of $\times 400$ using a Zeiss standard 18 microscope. The microscope was fitted with an HBO 
Table 1 Criteria of positivity by the IF test

\begin{tabular}{lll}
\hline $\begin{array}{l}\text { Appearance of antigen } \\
\text { FITC filter }\end{array}$ & FITC and Rhodamine filter & \\
\hline $\begin{array}{l}\text { Particles bright } \\
\text { fluorescent green }\end{array}$ & Particles dull green & + \\
$\begin{array}{l}\text { Particles dull green } \\
\text { Antigen dot dull green } \\
\text { (no particles visible) }\end{array}$ & $\begin{array}{c}\text { Particles orange/yellow } \\
\text { Antigen dot orange } \\
\text { (no particles visible) }\end{array}$ & - \\
\hline
\end{tabular}

50 mercury-vapour bulb using an epi-illumination system and a Zeiss filter set $10 \mathrm{H}$.

Positive reactions appeared as bright green, uniformly sized, 'pin-point' particles. These particles were mostly evenly distributed throughout the antigen dot, but some loose aggregates were present. Non-specific staining did occur because extraneous material present in the antigens sometimes also stained green. However, we found no difficulty in differentiating the pleomorphic debris from true particulate reactions. Our criteria for positive and negative reactions by the IF test using both the FITC excitation filter and the FITC and Rhodamine excitation filter are shown in Table 1. The end-point readings were taken as the highest dilution of serum or secretion producing a positive result.

\section{Results}

ANIMAL SERA

The results of testing mouse and rabbit antiserum prepared against HSV1 and HSV2 by the IF test against homologous, heterologous, and control antigens are shown in Table 2 . These results demonstrate that antiserum prepared against HSV1 reacts to the greatest degree with the homologous antigen whereas antiserum prepared against HSV2 reacts to equal titres with both HSV1 and HSV2 antigens.

Repeat tests over the course of six months using

Table 2 Levels of type-specific anti-herpes virus antibody detected by IF test in animal sera prepared against HSVI and HSV2

\begin{tabular}{lccl}
\hline Serum & \multicolumn{2}{l}{ Antigen } & \\
\cline { 2 - 4 } & $H S V 1$ & $H S V 2$ & Control \\
\hline Mouse & & 10 & 0 \\
Anti HSV1 & $320^{*}$ & 10 & 0 \\
Anti HSV2 & 80 & 80 & 0 \\
$\quad$ Normal & 0 & 0 & 0 \\
Rabbit & & 256 & 0 \\
Anti HSV1 & 2048 & 256 & 0 \\
Anti HSV2 & 512 & 512 & 0 \\
\hline
\end{tabular}

* Reciprocal end-point titre.
Table 3 Levels of type-specific anti-herpes $\operatorname{Ig} G$ and IgM antibody detected by IF test in sera from four patients with proven herpes ocular and genital infections

\begin{tabular}{|c|c|c|c|c|c|c|}
\hline \multirow[t]{3}{*}{ Patient } & \multicolumn{6}{|c|}{ Antigen } \\
\hline & \multicolumn{2}{|c|}{$H S V I$} & \multicolumn{2}{|c|}{$H S V 2$} & \multicolumn{2}{|c|}{ Control } \\
\hline & $\lg G$ & $\operatorname{Ig} M$ & $\operatorname{IgG}$ & $I g M$ & $I g G$ & $I g M$ \\
\hline 1 Ocular & $128^{*}$ & 8 & 0 & 0 & 0 & 0 \\
\hline 2 Ocular & 256 & 0 & 8 & 0 & 0 & 0 \\
\hline 3 Genital & 128 & $\overline{0}$ & 128 & 0 & 0 & $\mathbf{0}$ \\
\hline 4 Genital & 32 & 0 & 32 & 0 & 0 & $\mathbf{0}$ \\
\hline
\end{tabular}

* Reciprocal end-point titre.

the same antigens stored at $-70^{\circ} \mathrm{C}$ and mouse antisera stored at $-20^{\circ} \mathrm{C}$ showed no marked difference in the levels of anti-herpes antibodies detected.

HUMAN SERA

Initially, sera from four patients, two with ocular herpes infections and two with genital herpes infections, were screened against HSV1, HSV2, and control antigens using the IF test. Herpes simplex virus was isolated in cell culture from these four patients and was typed as HSV type 1 from the ocular infections and as HSV type 2 from the genital infections. Sera from patients with ocular infection reacted most strongly with HSV1 antigen whereas sera from patients with genital infection showed equal titres to both HSV1 and HSV2 antigens (Table 3).

Sera or whole blood from a total of 100 patients were tested by the IF test. Eighty patients had ocular herpes infection and 20 had microbiologically proven ocular adenovirus infections (controls). The sera from the control group were all negative for anti-herpes antibodies by the complement fixation test. In those patients with ocular herpes infections anti-herpes IgG at a dilution of $1 / 16$ or higher was detected in $75(94 \%)$ and anti-herpes IgM at a dilution of $1 / 8$ or higher in $31(39 \%)$ (Table 4), all reactions being at least four times higher against HSV1 antigen than against HSV2 antigen. No antiherpes antibodies were detected in patients with ocular adenovirus infections. The levels of antiherpes IgG and IgM detected in the blood of 68 patients with microbiologically proven herpes virus infections are shown in Table 5.

In 10 patients with ocular herpes infection, eye secretions (tears) were collected by sponges. The levels of anti-herpes IgG and IgA detected in the tears of these patients (Table 6) are compared to the levels of anti-herpes IgG and IgM detected in the blood, also collected by sponges. 
Table 4 Detection of type-specific anti-herpes $\operatorname{Ig} G$ and $\operatorname{Ig} M$ antibodies by IF test in blood from 102 patients

\begin{tabular}{|c|c|c|c|c|c|c|}
\hline \multirow[t]{2}{*}{ Clinical diagnosis } & \multirow[t]{2}{*}{ No. of patients } & \multicolumn{2}{|c|}{$H S V I$} & \multicolumn{2}{|c|}{$H S V 2$} & \multirow{2}{*}{$\begin{array}{l}\text { Total ro. o } \\
\text { patierts } \\
\text { positive }\end{array}$} \\
\hline & & $\lg G$ & $\operatorname{Ig} M$ & $\operatorname{IgG}$ & $\operatorname{Ig} M$ & \\
\hline Ocular herpes & 80 & $75^{*}$ & $31 \dagger$ & 12 & 0 & $75 t$ \\
\hline Isolation positive & 68 & 63 & 27 & 10 & 0 & 63 \\
\hline Isolation not done & 12 & 12 & 4 & 2 & 0 & 12 \\
\hline Genital herpes & 2 & 2 & 0 & 2 & 0 & $2 \S$ \\
\hline $\begin{array}{l}\text { Ocular adenovirus } \\
\text { (control group) }\end{array}$ & 20 & 0 & 0 & 0 & 0 & 0 \\
\hline
\end{tabular}

$* \operatorname{IgG}>1 / 16$.

$+\operatorname{IgM}>1 / 8$.

$\ddagger$ All titres highest against HSV1.

$\S A l l$ titres equal against HSV1 and HSV2.

Table 5 Distribution of levels of type-specific anti-herpes $\operatorname{IgG}$ and $\operatorname{Ig} M$ antibody detected by IF test in sera from 68 patients with ocular herpes infections and positive virus culture

\begin{tabular}{|c|c|c|c|c|c|c|c|c|c|}
\hline \multirow[t]{3}{*}{ Antigen } & \multirow[t]{3}{*}{ Ig class } & \multicolumn{7}{|c|}{ Number of sera } & \multirow[t]{3}{*}{ Total } \\
\hline & & \multicolumn{7}{|c|}{ Reciprocal herpes virus antibody titre } & \\
\hline & & 8 & 16 & 32 & 64 & 128 & 256 & 512 & \\
\hline \multirow[t]{2}{*}{ HSV 1} & IgG & 0 & 3 & 4 & 19 & 16 & 14 & 7 & 63 \\
\hline & IgM & 10 & 9 & 3 & 5 & 0 & 0 & 0 & 27 \\
\hline \multirow[t]{2}{*}{ HSV2 } & IgG & 0 & 7 & 3 & 0 & 0 & 0 & 0 & 10 \\
\hline & IgM & 0 & 0 & 0 & 0 & 0 & 0 & 0 & 0 \\
\hline
\end{tabular}

Table 6 Levels of type-specific anti-herpes $\operatorname{IgG}, \operatorname{Ig} M$, and $\operatorname{Ig} A$ antibodies detected by IF test in blood and tears from 10 patients with clinically diagnosed herpes ocular infections

\begin{tabular}{|c|c|c|c|c|c|c|c|c|}
\hline \multirow[t]{3}{*}{ Clinical diagnosis } & \multicolumn{4}{|l|}{ Blood } & \multicolumn{4}{|c|}{ Tears } \\
\hline & \multicolumn{2}{|c|}{$H S V 1$} & \multicolumn{2}{|c|}{$H S V 2$} & \multicolumn{2}{|c|}{$H S V I$} & \multicolumn{2}{|c|}{$H S V 2$} \\
\hline & $I g G$ & $\operatorname{Ig} M$ & $\operatorname{Ig} G$ & $\operatorname{Ig} M$ & $\operatorname{Ig} G$ & $\operatorname{Ig} A$ & $I g G$ & $\operatorname{Ig} A$ \\
\hline Primary herpes simplex & $128^{*}$ & 8 & 0 & 0 & 0 & 0 & 0 & 0 \\
\hline Dendritic ulcer & 64 & 8 & 0 & 0 & 8 & 0 & 0 & 0 \\
\hline Dendritic ulcer & 32 & 0 & 0 & 0 & 8 & 0 & 0 & 0 \\
\hline Dendritic ulcer & 16 & 0 & 0 & 0 & 0 & 0 & 0 & 0 \\
\hline Herpetic keratitis & 64 & 0 & 0 & 0 & 0 & 0 & 0 & 0 \\
\hline Herpetic keratitis & 64 & 0 & 0 & 0 & 0 & 0 & 0 & 0 \\
\hline Chronic corneal ulcer & 128 & 0 & 16 & 0 & 64 & 16 & 0 & 0 \\
\hline Recurrent herpetic keratitis & 128 & 8 & 0 & 0 & 32 & 32 & 0 & 0 \\
\hline Resolving herpetic keratitis & 256 & 0 & 16 & 0 & 0 & 0 & 0 & 0 \\
\hline
\end{tabular}

* Reciprocal end-point titre.

\section{Discussion}

The IF test described is shown to be sensitive for the detection of type-specific antibodies against herpes simplex virus.

The antigens required for this test can be grown in bulk in tissue culture. In this study we have used HeLa 229 cells for propagation of herpes virus but other cell culture systems, such as HEp 2, WI 38, and HEL, are similarly sensitive. We also found that simple differential centrifugation proved satisfactory for the purification and concentration of antigens. The more involved techniques of sucrose density centrifugation and 'Millipore' molecular separation were also tried but found to have no advantages over differential centrifugation.

The amount of antigen required for each test is minimal since one ampoule containing $0.3 \mathrm{ml}$ of purified virus can produce hundreds of slides. Studies on the storage of antigen showed that purified virus can be kept at $-70^{\circ} \mathrm{C}$ for at least six months without obvious deterioration in antigenicity. However, we 
found that repeated freeze-thawing reduced the antigenicity of the virus, and it was necessary to discard an ampoule after four freeze-thaw cycles. To economise on antigen, it is possible to prepare slides of fixed antigen in advance and to store them at $-20^{\circ} \mathrm{C}$. These slides can be used for periods of up to six months.

In this study anti-herpes antisera prepared in mice were absorbed with control antigen before testing since the same antigens were used to inoculate the mice as were used in the test itself. No prior absorption of the commercially prepared rabbit antisera or the human sera was found to be required.

Because of the small amounts of blood or local secretion required for this test $(0 \cdot 1 \mathrm{ml}$ approximately) we found it feasible to collect these specimens by saturating cellulose sponges. The method of sponge collection of blood after a finger prick is far simpler and more rapid than venepuncture and does not require highly trained staff.

In staining the antigen-antibody complexes with commercially prepared anti-species antiserum conjugated with FITC it is important to determine the optimum working dilution for each batch of conjugate before use.

IF positive reactions produced bright green uniform particles or clumps of particles. Occasionally some non-specific staining did occur but we found no problem in differentiating this amorphous debris from true particle reactions.

In our hands the IF test proved highly sensitive for detecting antibodies to herpes simplex virus. In 80 patients with clinical evidence of an active herpes ocular infection, antibody was detected in $94 \%$ of cases. No antibody was found in a control group of 20 patients with adenovirus infections who had previously been shown to be negative by complement fixation. Testing of animal sera specially prepared against HSV1 and HSV2 and blood from a few cases of herpes ocular and genital infections showed that this test can differentiate antibodies to the herpes virus serotypes responsible for the infection. We found that in HSV1 infection the highest level of antibody is against the homologous antigen whereas in HSV2 an equal antibody titre to both serotypes is seen. This result confirms the findings of Doerr et al. ${ }^{15}$

This test was also able to identify anti-herpes IgG, IgM, and IgA classes of antibody. The presence of anti-herpes IgM in the blood may be associated with active herpes virus infections. ${ }^{6}$ In studies of chlamydial infections it has been shown that the presence of IgM in the blood and of IgG and IgA in tears or cervical secretions is closely associated with active chlamydial infections of the eye ${ }^{11}$ or genital tract. ${ }^{12}$ Therefore it is hoped that the presence of these anti- bodies against herpes simplex virus in blood or local secretions may provide evidence of active herpetic infection.

The results of this study indicate that the IF test is a simple, rapid, and inexpensive method for detecting type-specific anti-herpes antibodies of different immunoglobulin classes. This fact, coupled with the ease of collecting blood and local secretions with cellulose sponges, should make the test a valuable technique for the routine serodiagnosis of herpes simplex virus infections.

We thank Dr M Pereira, Virus Reference Laboratory, Colindale Public Health Laboratory, for supplying herpes virus serotypes, and our colleagues at Moorfields Eye Hospital for collecting the clinical specimens. This work is supported by a locally organised research grant from Moorfields Eye Hospital, London.

\section{References}

${ }^{1}$ Rosenbaum MJ, Phillips IA, Sullivan EJ, Edwards EA, Miller LF. A simplified method of virus-tissue culture procedures in microtitration plates. Proc Soc Exp Biol Med 1963;113:224-9.

${ }^{2}$ Royston I, Aurelian L. The association of genital herpesvirus with cervical atypia and carcinoma in situ. Am J Epidemiol 1970;91:531-8.

${ }^{3}$ Skinner GRB, Thouless ME, Jordan JA. Antibodies to type 1 and type 2 herpes virus in women with abnormal cervical cytology. J Obstet Gynaec Brit Commonwealth 1971 ;78:1031-8.

${ }^{4}$ Smith JW, Adam E, Melnick JL, Rawls WE. Use of the ${ }^{51} \mathrm{Cr}$ release test to demonstrate patterns of antibody response in humans to herpesvirus types 1 and 2 . J Immunol 1972;109:554-64.

${ }^{5}$ Fuccillo DA, Moder FL, Catalano LW, Jr, Vincent MM, Sever JL. Herpesvirus hominus types 1 and 2: A specific microindirect hemagglutination test. Proc Soc Exp Biol Med 1970;133:735-9.

${ }^{6}$ Nahmias AJ, Shore SL, Del Buono I. Diagnosis by immunofluorescence of human viral infections with emphasis on herpes simplex viruses. In: Kurstak E, Morisset R, eds. Viral Immunodiagnosis. New York: Academic Press, 1974.

7 Nahmias AJ, Del Buono I, Schneweis KE, Gordon DS, Thies D. Type-specific surface antigens of cells infected with herpes simplex virus (1 and 2). Proc Soc Exp Biol Med 1971;18:321-7.

${ }^{8}$ Smith JW, Lowry SP, Melnick JL, Rawls WE. Antibodies to surface antigens of herpesvirus type 1 and 2 infected cells among women with cervical cancer and control women. Infect Immun 1972;5:305-10.

${ }^{9}$ Wang S-P, Grayston JT. Immunologic relationship between genital TRIC, lymphogranuloma venereum and related organisms in a new microtiter indirect immunofluorescence test. Am J Ophthalmol 1970;70: 367-74. 
10 Treharne JD, Darougar S, Jones BR. Modification of the microimmunofluorescence test to provide a routine serodiagnostic test for chlamydial infection. J Clin Pathol 1977;30:510-7.

11 Darougar S, Treharne JD, Minassian D, El-Sheikh H, Dines RJ, Jones BR. Rapid serological test for diagnosis of chlamydial ocular infections. $\mathrm{Br} J$ Ophthal 1978;62:503-8.

12 Treharne JD, Darougar S, Simmons PD, Thin RN. Rapid diagnosis $c t$ chlamydial infection of the cervix. Br J Vener Dis 1978;54:403-8.

${ }^{13}$ Powell KL, Watson DH. Some structural antigens of herpes simplex virus type 1. J Gen Virol 1975;29:
167-78.

${ }^{14}$ Lennette EH, Schmidt NJ. Diagnostic Procedures for Viral and Rickettsial Diseases. 3rd ed. New York: American Public Health Association Inc, 1964.

${ }^{15}$ Doerr HW, Rau M, Schmitz H. Typing of Herpes virus simplex hominis 1 and 2 by indirect immunofluorescence. Med Microbiol Immunol 1974;159: 137-40.

Requests for reprints to: Mr T Forsey, Virus Laboratory, Institute of Ophthalmology, Judd Street, London WC1H 9QS, UK.

\section{Reports and Bulletins prepared by the Association of Clinical Biochemists}

The following reports and bulletins are published by the Association of Clinical Biochemists. They may be obtained from The Publishing Department, British Medical Journal (ACB Technical Bulletins), B.M.A. House, Tavistock Square, London WC1H 9JR. Overseas readers should remit by British Postal or Money Order.

SCIENTIFIC REVIEWS (price $£ 1 \cdot 00 / \$ 2.00$ each)

1 The assessment of thyroid function March 1971 F. V. FLYNN and J. R. HOBBS

2 Renal function tests suitable for clinical practice January 1972 F. L. MTTCHELL, N. VEALL, and R. W. E. WATTS

3 Biochemical tests for the assessment of fetoplacental function May 1975 C. E. WILDE and R. E. OAKEY

4 Test of exocrine pancreatic function March 1977 A. H. GOWENLOCK

5 Assay of cholinesterase in clinical chemistry March 1979 ELSIE SILK, J. KING, and MARY WHITTAKER

TECHNICAL BULLETINS (price $£ 1.00 / \$ 2.00$ each)

22 Bilirubin standards and the determination of bilirubin by manual and technicon AutoAnalyzer methods January 1971 BARBARA BILLING, RUTH HASLAM, and $\mathrm{N}$. WALD

23 Interchangeable cells for spectrophotometers and fluorimeters September 1971 S. S. BROWN and A. H. GOWENLOCK

24 Simple tests to detect poisons March 1972 B. W. MEADE et al.

25 Blood gas analysers May 1972 K. DIXON

26 Kits for enzyme activity determination September 1972 s. B. ROSALKI and D. TARLOW

27 Assessment of pumps suitable for incorporation into existing continuous flow analytical systems November 1972 A. FLECK et al.
28 Routine clinical measurements of transferrin in human serum September 1973 K. DIXON

29 Control materials for clinical biochemistry (5th edition) September 1973 J. F. STEVENS

30 Notes on the quality of performance of serum cholesterol assays September 1973 s. s. BROWN

31 Determination of uric acid in blood and in urine July 1974 R. W. E. WATTs

32 A survey of amino acid analysers readily available in the United Kingdom September 1974 J. E. CARLYLE and P. PURKISS

33 Definitions of some words and terms used in automated analysis November 1974 A. FLECK, R. ROBINSON, S. S. BROWN, and J. R. HOBBS

34 Measurement of albumin in the sera of patients January 1975 LINDA SLATER, P. M. CARTER, and J. R. HOBBS

35 Investigation of the validity of temperature correction factors for serum aspartate and alanine transaminases March 1975 s. B. ROSALKI et al.

36 Factors influencing the assay of creatinine November 1975 J. G. H. COOK

37 A survey of enzyme reaction rate analysers readily available in the United Kingdom July 1977 R. A. SAUNDERS and R. F. BURNS

38 Transport of specimens for clinical chemistry analysis November 1977 P. WILDING, J. F. ZnLVA, and C. E. WILDE

39 A scheme for the evaluation of diagnostic kits May 1978 P. H. LLOYD 